\title{
Medullary cystic disease of the kidney: its occurrence in two siblings
}

\author{
Satya Paul Handa* \\ M.B. \\ ROBERT TENNANT \\ M.D.
}

The Hartford Hospital, Hartford, Connecticut

\begin{abstract}
Summary
Two cases of medullary cystic disease of the kidney in two siblings are presented. In both siblings there was an insidious onset of azotaemia and anaemia at an early age. The urinalyses were normal except for a trace of proteinuria and persistent low specific gravity. The kidneys were small by radiological studies and this was proved at necropsy. The gross microscopic appearances of the kidneys were consistent with medullary cystic disease. The literature on this subject and current views on the similarities between familial juvenile nephronophthisis and this condition are discussed.
\end{abstract}

\section{Introduction}

Medullary cystic disease of the kidney, a progressive renal disorder occuring in children and young adults, first describéd by Smith \& Graham (1945), was reviewed by Strauss in 1962. To date over forty cases of the entity have been reported in the world literature (Goldman et al., 1966; Herdman, Good \& Vernier, 1967). The condition is characterized by the insidious onset of uraemia, anaemia and other features of progressive renal disease, but without symptoms of urinary tract involvement. On post-mortem examination, the kidneys are contracted and scarred, and show extensive cyst formation in the medulla or in the region of the cortico-medullary junction.

Medullary cystic disease of the kidney is thought not to be related to sponge kidney, a condition characterized by multiple small cysts in the medullary region, with little or no evidence of impairment of renal functions.

The disorder called familial juvenile nephronophthisis was described by Fanconi et al. in 1951. Since then forty cases have been reported. Clinically these patients present with features similar to those of medullary cystic disease of the kidney.

\footnotetext{
*Present address: Renal Disease Section, Department of Medicine, V.A. Hospital, Washington, D.C.

Reprint requests to Dr Tennant, Hartford Hospital, Hartford, Connecticut.
}

Necropsy findings reveal gross or microscopic $\overrightarrow{\vec{H}}$ cysts in the medullary region of the kidney. At $\stackrel{\omega}{\sigma}$ present there is an ample evidence that medullary $\vec{D}$ cystic disease of the kidney and familial juvenile 3 nephronophthisis represent one and the same disorder (Mongeau \& Worthen, 1967; Strauss \& Sommers, 1967).

The occurrence of medullary cystic disease in two siblings prompted the present report.

\section{Case reports}

\section{Case 1}

R.B., a 20-year-old white male, was admitted to Hartford Hospital for the first time because of progressive weakness, headache and epigastrio pain associated with vomiting.

The patient had had enuresis until the age of 7 and nocturia during his entire life. At the age of 13, he experienced increased thirst, polyuria and fatiguability. A year later daily urine outputs were in the range of 8-10 litres; however, no $\stackrel{\unrhd}{\unrhd}$ craving for salt was noted. Subsequently he be- $\overrightarrow{\vec{D}}$ gan to complain of headache and muscle cramps. When he was evaluated in 1959 (at the age of 15), he was found to have a blood pressure of 170 / $110 \mathrm{mmHg}$, congenital ichthyosis and mild azotemia. Intravenous pyelogram revealed small kidneys. Over the next 4 years, his renal function showed a progressive decline (Table 1).

He was admitted to another hospital in July 1963 with symptoms of anorexia, weight loss and itching. The urine output and intensity of thirst had gradually decreased.

Physical examination revealed a pale, muscular boy with ichthyotic and pigmented skin. The N pulse was 120 , BP $154 / 100 \mathrm{mmHg}$. The thyroid was diffusely enlarged and a slight degree of lidlag was present. The heart was enlarged with a thrusting apex beat and a presystolic gallop. Lungs were clear.

Investigations. PCV $27.5 \%$, WBC $7700 / \mathrm{mm}^{3}$, with a normal differential. Urinalysis; specificgravity, $1.004 ; 2+$ protein and unremarkable sedi- 
ment. Radiological survey of skeletal system was consistent with renal osteodystrophy. Urine culture from bladder and both ureters was negative. Cystoscopic examination was unremarkable.

The patient was treated with large quantities of salt and fluid intravenously. There was significant improvement in his clinical state. The blood urea nitrogen (BUN) fell from 230 to $100 \mathrm{mg} / 100 \mathrm{ml}$. He was discharged to be followed by his private physician.

In September 1964 he began to complain of epigastric pain with nausea and was admitted to Hartford Hospital on 22 November 1964 because of vomiting.

On examination he was dehydrated and sallow. Pulse, 84 ; BP $184 / 80 \mathrm{mmHg}$. The remaining physical examination was similar to that of 1963 , but the fundi showed changes of azotemia and hypertension. Hb $8.2 \mathrm{~g} / 100 \mathrm{ml}$, BUN $295 \mathrm{mg} / 100 \mathrm{ml}$ and serum creatinine $20.7 \mathrm{mg} / 100 \mathrm{ml}$. The barium meal showed no abnormality.

The hospital course was that of chronic azotemia. Large volumes of saline infusions were given to replace urinary wastage of sodium, ranging $84-110 \mathrm{mEq} / 1$. In view of the small size of the kidneys with progressive azotaemia, the

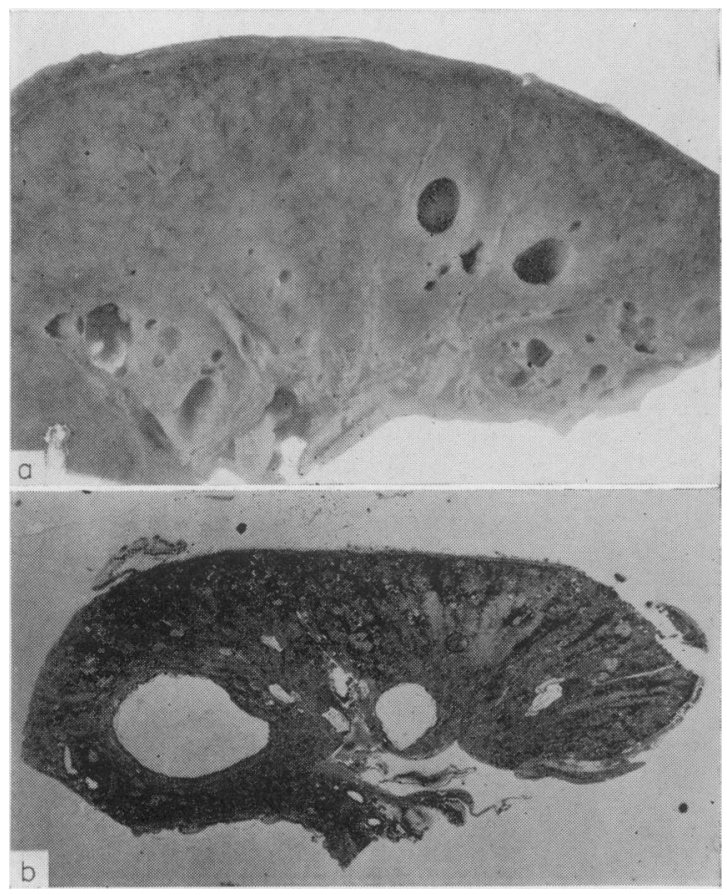

FIG. 1. (a) Case 1. Kidney showing diffuse scarring of cortex with numerous medullary cysts. (b) Case 2. Kidney section showing medullary cysts. $\mathrm{H} \& \mathrm{E}, \times 6$. clinical impression was that of renal disease rather than adrenal and studies of adrenal function were not done. Despite control of uraemia by dialysis, the patient developed tinnitus, deafness and Pseudomonas septicemia and he expired on 18 January 1964.

Necropsy. The skin showed a brown scaly appearance due to ichthyosis. Fourth toe on each foot was small. Heart weighed $520 \mathrm{~g}$, and showed marked left ventricular hypertrophy. Lungs showed basal congestion. The vertebral marrow was pale. Adrenals and parathyroids were grossly unremarkable. Thyroid was enlarged. Each kidney weighed $100 \mathrm{~g}$ and measured $7.5 \times 4 \mathrm{~cm}$. The capsules could be stripped easily, revealing smooth cortical surfaces. On cut section, the parenchyma was firm in consistency; the cortices were atrophic. The medullary areas, especially in the pyramids, showed numerous smooth-walled cysts which varied in size from 0.2 to $1 \mathrm{~cm}$ in diameter (Fig. 1a). The pelves and calyces were unremarkable. The ureters were normal. Both renal arteries were normal.

Histology: Sections of the kidney showed

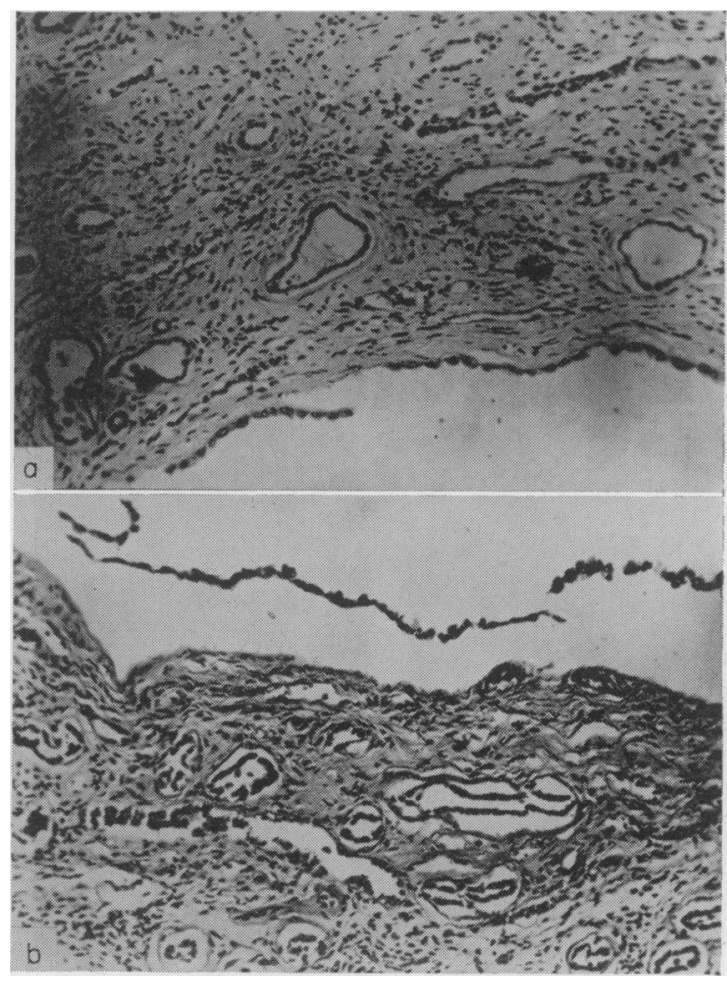

FIG. 2. (a) Case 1. (b) Case 2. Shows wall of medullary cysts with flattened epithelial lining and increase in fibrous tissue between collecting tubules. H \& E, $\times 60$. 
numerous cysts in the medulla. These were lined by low cuboidal epithelium (Fig. 2a). The adjacent collecting tubules were compressed and distorted. There was a diffuse increase in the interstitial fibrous tissue in the medulla. The cortex was markedly narrowed and was replaced by diffuse interstitial fibrous tissue. The convoluted tubules were atrophic and many were encircled by bands of collagenized tissue. The glomeruli showed fibrous thickening of Bowman's capsule and many glomeruli were hyalinized (Fig. 3a). Many capsular spaces were dilated. There was a scant diffuse infiltration of lymphocytes in the interstitial tissue. Protein casts were present in many of the tubules. There were also several lakes of proteinaceous material present in the interstitium of the cortex (Fig. 4a). This material took a strongly positive PAS stain. There was no evidence of acute inflammatory reaction present.

\section{Case 2}

J.B., sister of R.B., was first seen in August 1953 , at the age of 12 for the investigation of anaemia. $\mathrm{Hb} 6.7 \mathrm{~g} / 100 \mathrm{ml}$. Urinalysis ; specific

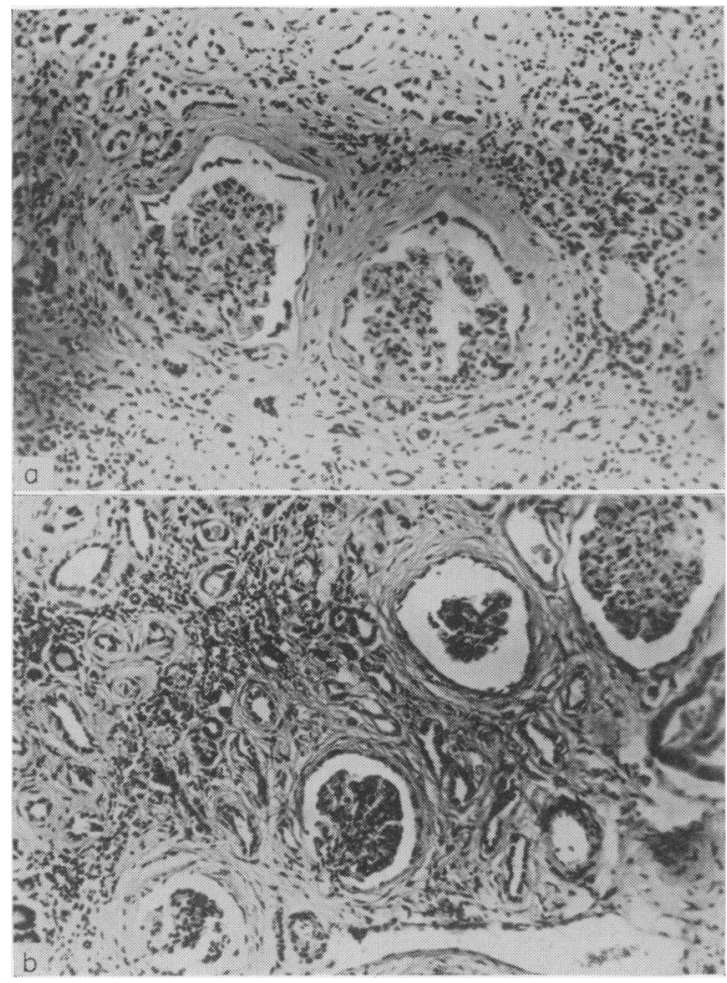

Fig. 3. (a) Case 1. (b) Case 2. Diffuse interstitial fibrosis with atrophy of tubules and fibrous thicking of glomerular capsules present in both cases. H \& E, $\times 60$. gravity $1 \cdot 016,3+$ protein, sediment unremarkable. BUN $187 \mathrm{mg} / 100 \mathrm{ml}$. Subsequently she was admitted to another hospital with an acute respiratory infection, when she was found to be chron- $c$ ically ill with a BP $140 / 90 \mathrm{mmHg}$. Pulse $104 / \mathrm{min}$. The kidneys were seen to be small on flat plate $\stackrel{\vec{F}}{+}$ of the abdomen, but could not be visualized in the IVP. There was an overall decreased density of the bones. She was put on a low protein diet, $\frac{\bar{D}}{\vec{D}}$ calcium lactate and amphogel. With this regimen, $\stackrel{\curvearrowright}{\Omega}$ the azotaemia improved and BUN fell to $69 \mathrm{mg} / \%$ $100 \mathrm{ml}$ in 2 months. Other laboratory data $\vec{D}$ presented in Table 1. Her anaemia was attributed to azotemia due to hypoplastic kidneys. The $\vec{\omega}$ clinical course remained stable and she was dis- $\stackrel{\sigma}{\partial}$ charged.

In November 1955, at the age of $14 \frac{1}{2}$ she 3 . entered New Britain General Hospital complain- $\vec{t}$ ing of vomiting, diarrhoea and severe anaemia. or Her skin was scaly and pigmented. Pulse 120, $\vec{\sigma}$

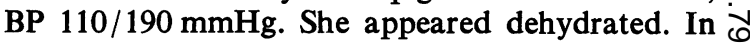
the hospital she suffered recurrent convulsive $N$ seizures and died a week after admission.

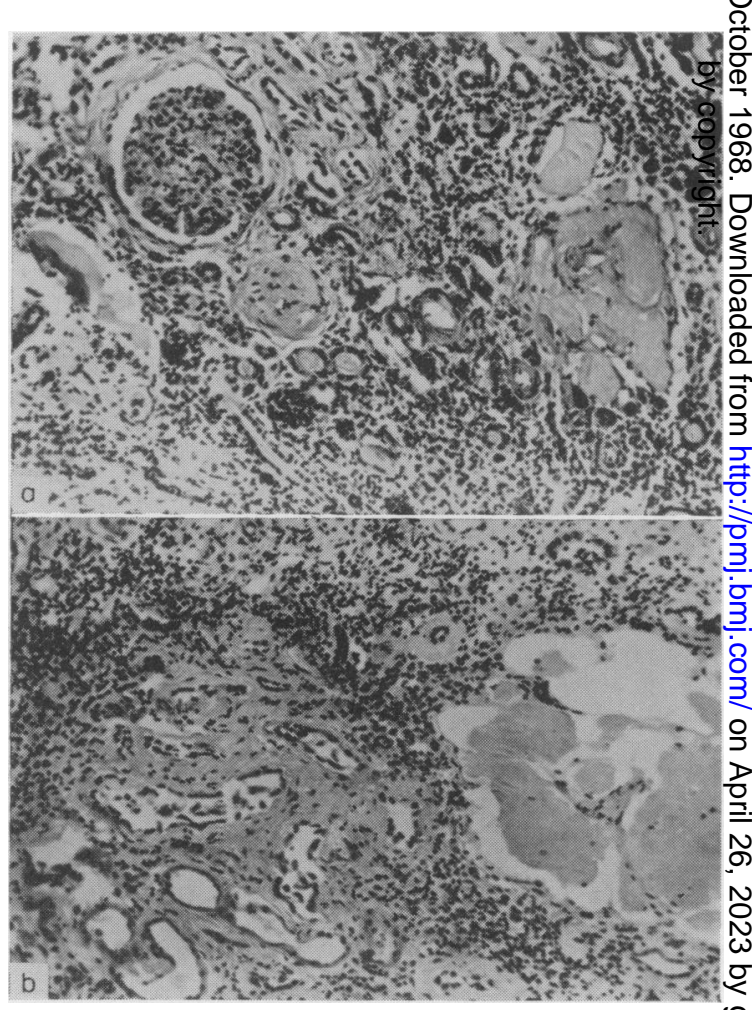

FIg. 4. (a) Case 1. (b) Case 2. Interstitial fibrosis of cortex with proteinacious material deposited in interstitium. Slight diffuse lymphocytic infiltration of stroma. $H \& E, \times 60$. 
Necropsy. The body was that of a small white girl measuring $4 \frac{1}{2} \mathrm{ft}$ in length and weighing $85 \mathrm{lb}$. The heart weighed $250 \mathrm{~g}$ and showed moderate hypertrophy of the left ventricle. The kidneys were small: right kidney $70 \mathrm{~g}$ and the left $90 \mathrm{~g}$. The capsules could be stripped with ease; the surfaces were slightly granular; the cortex and medulla could not be differentiated. There were multiple cysts present, predominantly in the medullary region (Fig. 1b). The cysts were unilocular and smooth-walled. There was no communication between cysts and pelves. They measured $1-4 \mathrm{~cm}$ in diameter. The pelves and ureters had pale linings and were normal except for slight dilatation of the right pelvis. Lungs showed right lower lobe hemorrhagic pneumonia

TABLE 1

Laboratory data

\begin{tabular}{|c|c|c|c|c|c|c|c|c|c|c|c|}
\hline Date & Urine & $\begin{array}{l}\text { Haemato- } \\
\text { crit or } \\
\text { haemo- } \\
\text { globin }\end{array}$ & $\begin{array}{l}\text { Blood } \\
\text { urea } \\
\text { nitrogen } \\
(\mathrm{mg} / \\
\quad 100 \mathrm{ml})\end{array}$ & $\begin{array}{l}\text { Calcium } \\
(\mathrm{mg} / \\
100 \mathrm{ml})\end{array}$ & $\begin{array}{l}\text { Phos- } \\
\text { phorus } \\
(\mathrm{mg} / \\
100 \mathrm{ml})\end{array}$ & $\begin{array}{l}\text { Sodium } \\
(\mathrm{mEq} / \mathrm{l})\end{array}$ & $\begin{array}{l}\text { Potas- } \\
\text { sium } \\
(\mathrm{mEq} / \mathrm{l})\end{array}$ & $\begin{array}{l}\text { Chloride } \\
(\mathrm{mEq} / \mathrm{l})\end{array}$ & $\begin{array}{l}\text { Carbon } \\
\text { dioxide } \\
(\mathrm{mEq} / \mathrm{l})\end{array}$ & $\begin{array}{l}\text { C } \\
\text { Alkaline cl } \\
\text { phos- an } \\
\text { phatase (m }\end{array}$ & $\begin{array}{l}\text { Creat. } \\
\text { clear- } \\
\text { ance } \\
(\mathrm{ml} / \mathrm{min})\end{array}$ \\
\hline \multicolumn{12}{|l|}{ R.B. } \\
\hline $\begin{array}{l}\text { September } \\
1959\end{array}$ & $\left.\begin{array}{l}\text { Alb. } 2+ \\
\text { WBC 1-3 } \\
\text { RBC 2-5 }\end{array}\right\}$ HPF & $11 \cdot 2 \mathrm{~g} / 100 \mathrm{ml}$ & 35 & $9 \cdot 3$ & $5 \cdot 2$ & - & - & - & - & $8 \cdot 2(\mathrm{KA})$ & 53 \\
\hline $\begin{array}{l}\text { July } \\
1960\end{array}$ & $\begin{array}{l}\text { S.G. } 1004 \\
\text { Alb. } 5 \mathrm{mg} / 100 \mathrm{ml} \\
\text { WBC 1-3 HPF }\end{array}$ & $12.0 \mathrm{~g} / 100 \mathrm{ml}$ & 40 & $9 \cdot 2$ & $4 \cdot 1$ & - & - & -. & - & - & - \\
\hline $\begin{array}{l}\text { June } \\
1961\end{array}$ & $\begin{array}{l}\text { S.G. } 1006 \\
\text { Alb. } 15 \mathrm{mg} / 100 \mathrm{ml}\end{array}$ & $10.6 \mathrm{~g} / 100 \mathrm{ml}$ & 42 & - & - & - & - & - & - & - & - \\
\hline $\begin{array}{l}\text { October } \\
1962\end{array}$ & $\begin{array}{l}\text { S.G. } 1003 \\
\text { Alb. } 2+\end{array}$ & $30 \%$ & 59 & $8 \cdot 4$ & $4 \cdot 2$ & - & - & - & - & - & - \\
\hline $\begin{array}{l}\text { July } \\
1963\end{array}$ & 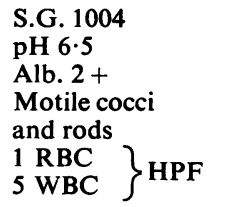 & $\begin{array}{l}27 \cdot 5 \% \text { and } \\
9 \cdot 3 \mathrm{~g} / 100 \mathrm{ml}\end{array}$ & 230 & $5 \cdot 6$ & $5 \cdot 5$ & 135 & $5 \cdot 4$ & 100 & $6 \cdot 0$ & $3 \cdot 4$ (BLU) & J) - \\
\hline $\begin{array}{l}\text { September } \\
1964\end{array}$ & - & $20-25 \%$ & 87 & $10 \cdot 9$ & - & - & - & - & - & - & - \\
\hline $\begin{array}{l}22 \text { Nov } \\
1964\end{array}$ & $\begin{array}{l}\text { S.G. } 1007 \\
\text { Alb. } 3+ \\
\text { Sugar } 3+\end{array}$ & $8.5 \mathrm{~g} / 100 \mathrm{ml}$ & 295 & $8 \cdot 8$ & $4 \cdot 7$ & 142 & $6 \cdot 9$ & 112 & 14 & 11 (KA) & 1.9 \\
\hline $\begin{array}{l}7 \mathrm{Dec} \\
1964\end{array}$ & $\begin{array}{l}\text { Same but no } \\
\text { sugar-24 hr } \\
\text { urinary protein } \\
\text { output } 13 \cdot 1 \mathrm{~g}\end{array}$ & & 260 & $9 \cdot 8$ & $6 \cdot 8$ & 130 & $6 \cdot 2$ & 97 & 19 & - & - \\
\hline \multirow{2}{*}{\multicolumn{2}{|c|}{$\begin{array}{l}\text { After dialysis } \\
\text { on } 13 \mathrm{Dec} \\
\text { Terminally }\end{array}$}} & $29 \%$ & 44 & $9 \cdot 3$ & $6 \cdot 2$ & 138 & $5 \cdot 6$ & 103 & 21 & - & - \\
\hline & & $18 \%$ & 147 & $7 \cdot 4$ & - & 125 & $7 \cdot 6$ & - & 18 & - & - \\
\hline \multicolumn{12}{|l|}{ J.B. (sister) } \\
\hline 1953 & $\begin{array}{l}\text { S.G. } 1016 \\
\text { Alb. } 30 \mathrm{mg} / 100 \mathrm{ml}\end{array}$ & $6 \cdot 7 \mathrm{~g} / 100 \mathrm{ml}$ & 187 & - & - & - & - & - & - & - & - \\
\hline $\begin{array}{l}\text { January } \\
1954\end{array}$ & - & $7 \mathrm{~g} / 100 \mathrm{ml}$ & 69 & 7 & $5 \cdot 2$ & 137 & $4 \cdot 2$ & $105 \cdot 6$ & $17 \cdot 4$ & - & - \\
\hline $\begin{array}{l}\text { March } \\
1954\end{array}$ & - & - & $62 \cdot 5$ & 6 & $5 \cdot 7$ & 141 & $4 \cdot 2$ & $104 \cdot 8$ & $16 \cdot 5$ & - & - \\
\hline $\begin{array}{l}\text { August } \\
1954\end{array}$ & $\begin{array}{l}\text { S.G. } 1005 \\
\text { Alb. } 1+ \\
\text { No bacteria }\end{array}$ & $7 \mathrm{~g} / 100 \mathrm{ml}$ & 105 & $6 \cdot 4$ & $5 \cdot 2$ & 133 & $5 \cdot 0$ & $99 \cdot 6$ & $18 \cdot 5$ & - & - \\
\hline $\begin{array}{l}\text { November } \\
1955\end{array}$ & Same & $4.6 \mathrm{~g} / 100 \mathrm{ml}$ & 215 & $7 \cdot 0$ & $5 \cdot 4$ & 130 & $5 \cdot 0$ & 77 & 17 & - & - \\
\hline
\end{tabular}


and the hilar nodes were enlarged. Three parathyroid glands were found and were unremarkable. The right adrenal weighed $9 \mathrm{~g}$ and the left $11 \mathrm{~g}$.

Histology. Kidneys of normal structural pattern. Sections showed changes which were strikingly similar to those seen in the sibling (Figs. 2b, $3 \mathrm{~b}$ and $4 \mathrm{~b}$ ). The same cystic disease was present in the medulla with several cysts of large size present in the pyramids. No cyst was present in the cortex. The cortex was thin with marked interstitial fibrosis present. Most tubules were atrophic and the glomeruli were hyalinized. Lakes of proteinaceous material were seen in the interstitial tissue. In some areas this material appeared to have its origin from rupture of over-distended tubules with discharge of their contents into the stroma. There was scant lymphocytic infiltration present. Some arteries showed fibrous thickening of their walls, but this was not a prominant feature.

\section{Family history}

The family has been reluctant for any investigative search in renal disease. We could evaluate mere historical aspects of thirty-one members in four generations. There has been no loss of any member of the family at a younger age and deaths in adults were either because of old age or diseases unrelated to the kidney. Both parents are healthy. An intravenous pyelogram done on the mother of these siblings was unremarkable. Two other siblings, both boys, age 15 and 11 , are living and apparently free from renal disease. When possible the other members of this family will be studied and reported.

\section{Discussion}

Cystic changes in the kidneys are encountered in a variety of anatomical disorders and pathological entities. Each cystic disease is characterized by a relatively uniform clinical picture. There is a large number of published studies on polycystic (Dalgaard, 1963 ; Rall \& Odel 1949; Simon \& Thompson, 1955) and medullary sponge kidneys (Ekstrom et al., 1959) and Strauss (1962) and other observers (Goldman et al., 1966) postulate cystic disease of the medulla as a distinct clinical entity. Clinically this disease is characterized by polyuria, polydipsia, severe anaemia, azotaemia and salt-wasting at a young age. There are no significant urinary abnormalities. Radiologic studies usually reveal small kidneys.

The onset of renal disease at an early age in both our cases warrants comments on hereditary renal disease. Hereditary pyelonephritis and glomerulonephritis, histologically different from acquired types, have been well recognized in the past few years (Perkoff et al., 1951, 1958 ; Reyers- $\underset{z}{\lessgtr}$ bach \& Butler 1954; Whalen et al., 1961). In the $\stackrel{\square}{\circledR}$ usual case of hereditary nephritis, the onset is $c$ in infancy, with proteinuria, painless haema- $\overrightarrow{\vec{F}}$ turia and pyuria. The severity of the symptoms is more pronounced in males and progressive renal functional impairment leads to death before the age of 30 . The development of deafness, though of a mild type in Case 1 , was similar to a common $\stackrel{\mathbb{D}}{\square}$ finding in hereditary nephritis. It was probably i unrelated to the underlying renal disease.

Familial involvement in polycystic disease of the kidneys has been well documented (Dalgaard, $\vec{\omega}$ 1963 ; Potter, 1961) and there is ample evidence $\frac{\sigma}{0}$ (Ferguson, 1949) that the disease in adults is inherited as an autosomal dominant trait. Occasional reports of familial medullary sponge $\vec{f}$ kidney have also been published (Copping, 1967). or Strauss in 1962, in his review of medullary cystic $\vec{\sigma}$

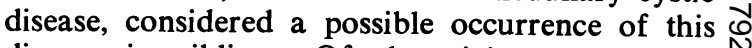
disease in siblings. Of the eighteen cases he reviewed, one had a twin brother with impairment of renal function, and the older brother of the second patient had cortical changes in the renal biopsy, similar to those seen in the kidneys of the patient at autopsy; the blood urea nitrogen was $40 \mathrm{mg} / 100 \mathrm{ml}$. Since then six families with thî $\vec{\varphi}$ entity have been reported (Gardner et al., 1967 Goldman et al., 1966 ; Herdman et al., 1967 ; Newe ton, 1964; Mongeau \& Worthen, 1967). The family of five generations studied by Goldman et al. (1966) had eleven members afflicted with medullary cystic disease. The sex distribution among those patients was four males to seven females and its transmission was assumed to be on a dominant gene basis; however, the sporadic occurrence of this disease in sibships suggest a recessive form of inheritance (Herdman et al., 1967; Mongeau \& Worthen, 1967).

Systemic anatomical abnormalities are frequently observed in patients with polycystic disease of the kidneys (Potter, 1961; Melnick, 1955) and occasionally with medullary sponge kidney (Morris et al., 1965). Hogness \& Burnell (1954) described four patients with medullary cystic disease of the kidney and demonstrated an association of cysts in the pancreas, stenosis of the renal arteries and in one of them a club-foot. The presence of congenital ichthyosis and short fourth toes on each foot in Case 1 suggest a developmental spectrum of anomalies. Congenital ichthyosis has been agreed to be an irregularly inherited disorder (Ellis, 1951) and endocrine, psychic and neurological abnormalities are associated in some of the cases (Aquilera, 1955). The medullary cysts co:ıld be a part of this general phenomenon. 
However, the absence of congenital malformations in other reported cases excludes such a hypothesis and supports the view that association of developmental abnormalities may be incidental or a reflection of multiple gene abnormalities in this particular patient.

In the early part of this century, the explanation of the development of medullary cysts was based on the theory proposed by Kampmeier (1923). According to that, the first primary generation of uriniferous tubules developing from mesonephric mesenchyme come to lie in the medullary region as the subsequent generations develop and unite with the collecting tubules. The primary or vestigeal tubules normally undergo cystic degeneration. The persistence and continuing degeneration in the primary uriniferous tubules result in development of the cystic disease. Potter (1961) supported this as a cause of the formation of an occasional cyst in the medulla.

Recent reports allude to the possible role of an inborn error of metabolism leading to functional and structural changes in the kidneys (Herdman et al., 1967; Mongeau \& Worthen, 1967). This consideration is based upon studies of cystic changes in the kidneys of rats experimentally produced by feeding them diphenylamine (Kime et al., 1962) and observations of clinical and histological similarities of Balkan endemic toxic nephropathy to those of cystic disease of the renal medulla (Hall et al., 1965). Because of the familial occurrence of cystic disease, it can be surmised that there is a genetically common enzyme defect leading to accumulation of nephrotoxic material produced endogenously. However, the sporadic occurrence in a family could be ascribed to exogenous nephrotoxins which the body is unable to metabolize. The nature of these toxins is unknown.

The literature over the past few years reveals similarities between medullary cystic disease of the kidney and familial juvenile nephronophthisis (Mongeau \& Worthen, 1967; Strauss \& Sommers, 1967). Clinically both entities are seen at an early age; however cases have been reported in older children and young adults. In contrast to medullary cystic disease where inheritance demonstrates both dominant and recessive traits familial juvenile nephronophthisis is usually a recessive trait. Von Sydow \& Ranstrom (1962) summarized the data on fifty-one members of thirteen families (tweny-six males and twentyfive females) reported up to 1962. Histological lesions of nephronophthisis were present in thirteen instances (six males and seven females) at necropsy and a history of renal disease was present in eighteen additional individuals (nine males, nine females). A history of consanguinity among parents, an uncommon occurrence in medullary cystic disease, was documented in three families. In the usual case, the onset is in infancy with hypotonic polyuria, polydipsia and progressive renal function impairment with a fatal outcome in 5-10 years.

The kidneys in nephronophthisis are usually contracted and scarred. Cysts are not uniformly seen in the medulla. Mongeau \& Worthen (1967) in their review of the literature found twenty cases with autopsy data and noted macroscopic and microscopic cysts in eight and twelve instances respectively. The morphological findings in the kidneys were well summarized by Ivemark, Ljungqvist \& Barry (1960). The significant pathological feature was that of tortuous and lengthy loops of Henle with occasional communicating cyst formation. The basement membrane of these loops was enormously thickened and they postulated that occurrence of cysts and glomerular alterations were secondary to the defect in the loops of Henle.

The gross and microscopic appearance of the kidneys in both our cases are strikingly similar to those described by Strauss (1962) and others (Hogness \& Burnell, 1954; Kerlan \& Russell 1963). The typical microscopic lesions in these cases consist of hyalinization of glomeruli, periglomerular fibrosis and atrophy of the tubules. On micro-dissection, cysts appear to arise from distal tubules; however no communications with collecting tubules are seen. Electron microscopy of renal tissue from such patients demonstrates irregular thicking of the basement membrane of the cysts and dilated tubules (Goldman et al., 1966).

In common with other patients described in the literature both siblings showed clinical features of anaemia and progressive azotaemia. The urinary sediments had been unremarkable. Case 1 also had a clinical picture of salt-wasting similar to patients described by others (five cases by Strauss, 1963 ; three cases, Goldman et al., 1966 ; one case, Herdman et al., 1967). Clinical symptoms included polyuria, polydipsia and muscle cramps. Throughout their clinical course, their urine was hypotonic.

\section{Acknowledgment}

We are indebted to Dr Thomas Madden of the Department of Pathology of New Britain General Hospita!, New Britain, Connecticut, who furnished the material on the second case. 


\section{References}

Aquilera Maruri, C. (1950) Ictiosis vulgaris (psicoectodermosis) Bol. Inst. Patol. Med. 5, 84. Recorded from Systemic Associations and Treatment of Skin Diseases (1955) (Ed. by Kurt Weiner), p. 349. Mosby, St Louis.

CopPING, G.A. (1967) Medullary sponge kidney: Its occurrence in a father and daughter. Can. med. Ass. J. 96, 608.

DalgaARD, O. Z. (1963) Polycystic disease of the kidneys. Diseases of the Kidney (Ed. by M. B. Strauss and L. G. Welt), p. 907. Little, Brown, Boston.

Ekstrom, T., Engfelt, B., LAgergren, C. \& Lindvall, N. (1959) Medullary Sponge Kidney; A Roentgenologic, Clinical, Histopathologic and Biophysical Study. Almqvist \& Wiksell, Stockholm.

Ellis, F.A. (1951) Universal ichthyosis. Arch. Derm. Syph. (Chic.), 63, 252.

Fanconi, G., Hanhart, E., Von Albertini, A., Euhlinger, E., Dolivo, G. \& Prader, A. (1951) Die familiare juvenile nephronophthisis. Helv. Paediat. Acta, 6, 1.

FERGUSON, J.D. (1949) Observations on familial polycystic disease of the kidney. Proc. R. Soc. Med. 42, 806.

Gardner, K.D., JR, Swenson, R.S., Rossman, K.J. \& Goldman, S.H. (1967) Further experience with cystic disease of the renal medulla. Clin. Res. 15, 358.

Goldman, S.H., Walker, S.R., Merigan, T.C., Gardner, K.D. \& BulL, J.M.C. (1966) Hereditary occurrence of cystic disease of the renal medulla. New Engl. J. Med. 274, 984.

Hall, P.W., Dammin, G.J., Griggs, R.C., Fajgelu, A., ZIMONJIC, B. \& GAON, J. (1965) Investigation of chronic endemic nephropathy in Yugoslavia. Amer. J. Med. 39, 210.

Herdman, R.C., Good, R.A. \& Vernier, R.L. (1967). Medullary cystic disease in two siblings. Amer. J. Med. 43, 335.

Hogness, J.R. \& BuRnell, J.M. (1954) Medullary cysts of kidneys. Arch. intern. Med. 93, 355.

IVEMARK, B.I., LJUNGQVisT, A. \& BARRY, A. (1960) Juvenile nephronophthisis. II. A histological and microangiographic study. Acta paediat. scand. 49, 480.

KAMPMEIER, O.F. (1923) Hitherto unrecognised mode of origin of congenital renal cysts. Surg. Gynec. Obstet. 36, 208.

Kime, S.W., JR, McNamara, J.J., Luse, S., Farmer, S., Silbert, C. \& BRICKER, N.S. (1962) Experimental polycystic renal disease in rats. Electron microscopy, function, and susceptibility to pyelonephritis.J.Lab. clin. Med. 60, 64.
Kerlan, M. \& Russel, O.Q. (1963) Cystic disease of renal medulla. J. Tenn. med. Ass. 56, 330.

MelniCK, P.J. (1955) Polycystic liver; analysis of seventy cases. Arch. Path. 59, 162.

MongeaU, J.G. \& Worthen, H.G. (1967) Nephronophthisis and medullary cystic disease. Amer. J. Med. 43, 345.

Morris, R.C., Yamauchi, H., Palubinskas, A.J. \& HowenSTINE, J. (1965) Medullary sponge kidney. Amer. J. Med. $38,883$.

Newton, W. (1964) A comment. Transactions Midwest Society of Pediatric Research, p. 7. Winnipeg.

Perkoff, G.T., Stephens, F.E., Dolowitz, D.A. \& Tyler, F.H. (1951) A clinical study of hereditary interstitial pyelonephritis. Arch. intern. Med. 88, 191.

Perkoff, G.T., Nugent, C.A., Jr, Dolowitz, D.A., STePhens, F.E., Carnes, W.H. \& Tyler, F.H. (1958) A follow-up study of hereditary chronic nephritis. Arch. intern. Med. 102, 733.

PotTer, E.L. (1961) Pathology of the Fetus and Infant, 2nd edn. Yearbook Medical Publishers, Chicago.

RALL, J. E. \& Odel, H.M. (1949) Congenital polycystic disease of kidney; review of literature and data on 207 cases. Amer. J. med. Sci. 218, 399.

Reyersbach, G.C. \& Butler, A.M. (1954) Congenital hereditary hematuria. New Engl. J. Med. 251, 377.

Simon, H.B. \& Thompson, G.H. (1955) Congenital renal polycystic disease. A clinical and therapeutic study of three hundred and sixty-six cases. J. Amer. med. Ass. 159, 657.

Smith, C.H. \& Graham, J.B. (1945) Congenital medullary cysts of kidneys with severe refractory anemia. Amer. J. Dis. Childh. 69, 369.

Strauss, M.B. (1962) Clinical and pathological aspects of cystic disease of renal medulla; analysis of eighteen cases Ann. intern. Med. 57, 373.

Strauss, M.B. (1963) Medullary cystic disease. Diseases of the Kidneys (Ed. by M. B. Strauss and L. G. Welt), p. 938 Little, Brown, Boston.

Strauss, M.B. \& Sommers, S.C. (1967) Medullary cystic disease and familial juvenile nephronophthisis. New. Engl. J. Med. 277, 863.

Von Sydow, G. \& Ranstrom, S. (1962) Familial juvenile nephronophthisis. Acta paediat. scand. 51, 561.

Whalen, R.E., Huang, S., Preschel, E. \& McIntosh, H.D. (1961) Hereditary nephropathy, deafness and renal foam cells. Amer. J. Med. 31, 171. 